\title{
Human communities living in the central Campania Plain during eruptions of Vesuvius and Campi Flegrei
}

\author{
Mauro A. Di Vito*,1, Paola Aurino², Giuliana Boenzi², Elena Laforgia ${ }^{2}$, Ilaria Rucco ${ }^{3}$ \\ (1) Istituto Nazionale di Geofisica e Vulcanologia, Sezione di Napoli Osservatorio Vesuviano \\ (2) MIC, Soprintendenza Archeologia, Belle Arti e Paesaggio per l'area metropolitana di Napoli, \\ Soprintendenza Archeologia, Belle Arti e Paesaggio per il Comune di Napoli \\ (3) Heriot Watt University, School of Engineering and Physical Sciences, Edinburgh, EH14 4AS United Kingdom
}

Article history: received June 27, 2021; accepted September 15, 2021

\begin{abstract}
Archaeological and volcanological studies have revealed that eruptions of Neapolitan volcanoes have conditioned human settlement patterns since prehistoric times. The occurrence of high intensity explosive eruptions, interspersed with long periods of quiescence, has characterized the last $10 \mathrm{ka}$ of activity of these volcanoes. Geoarchaeological studies, carried out in advance of investigations for the construction of the Rome-Naples and the new Naples-Bari railway lines, have made possible a detailed reconstruction of human presence in the central part of the Campania Plain up to the coastal strip, between the late Neolithic and the late Bronze Age. The examined chronological interval includes sequences of pyroclastic deposits erupted by both Campi Flegrei and Somma-Vesuvius, and paleosols with evidence of anthropic frequentation.

Altogether, the geoarchaeological data have provided a detailed picture of human settlement and activities through time with a particular focus on a long period of quiescence of the two volcanoes and also during their intense activity.
\end{abstract}

Keywords: Campania Plain; Neapolitan Volcanoes; Archaeology; Volcanology.

\section{Introduction}

The Campania region is distinguished by a marked geological and geomorphological difference between its eastern and western parts. The eastern is largely mountainous or hilly, a sector of the Apennine chain, while the western part is mainly flat and includes the Campania Plain and the Sele Plain, two graben structures which occupy the coastal strip. These plains are separated by the Sorrento Peninsula ridge (Figure 1). Furthermore, the Tyrrhenian part of the Campania Plain is dominated by a series of Quaternary volcanic edifices.

The Campania Plain is elongated NW-SE and is filled by Plio-Quaternary sedimentary and volcanic deposits [Ippolito et al., 1973]. The Apennines are a fold and thrust belt, composed of Meso-Cenozoic carbonate and Late Tortonian-Messinian siliciclastic deposits, which borders the northern, eastern, and southern margins of the Plain [Bonardi et al., 1988]. 


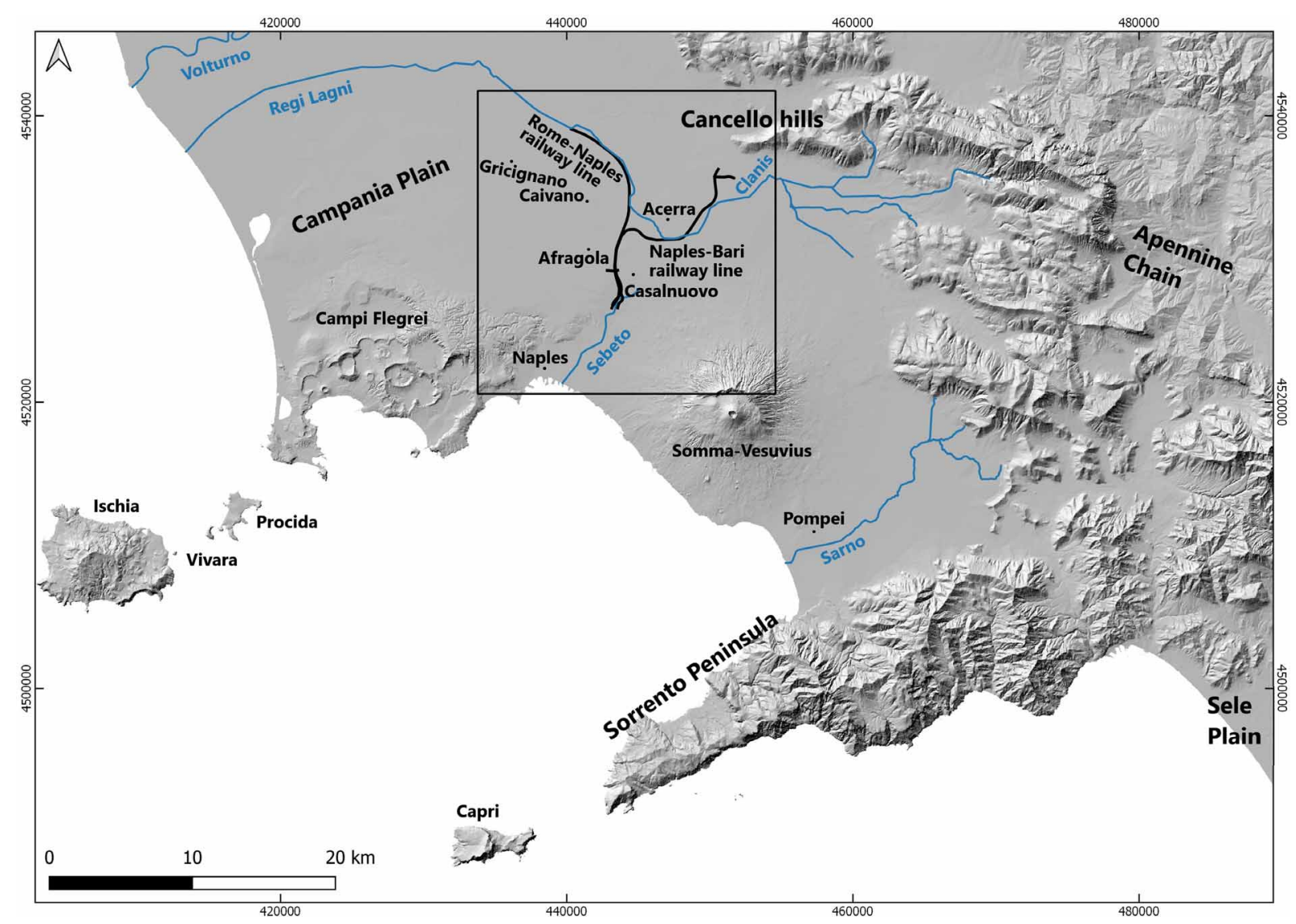

Figure 1. Morphological map of the central Campania region. The black box indicates the studied area, reported in figures $4,6,8$ and 9.

Four main volcanoes are present in this area: Somma-Vesuvius, Campi Flegrei, Ischia, and Procida (Figure 1). The onset of volcanic activity occurred in about 300-400 ka in the Vesuvian area [Principe et al., 1987; Brocchini et al., 2001], >150 ka in the Isle of Ischia [Poli et al., 1987], >80 ka in the Campi Flegrei area [Scarpati et al., 2013], and >70 ka at Procida [Rosi et al., 1988].

Only three of these volcanoes are still active today: Somma-Vesuvius, Campi Flegrei and Ischia [D’Argenio et al., 1973; Doglioni, 1991; Orsi et al. 2003; Santacroce et al., 2003; de Vita et al., 2010].

These volcanoes have produced numerous explosive and effusive eruptions. The largest explosive events affecting the Plain are associated with Somma-Vesuvius and Campi Flegrei caldera activity. Somma-Vesuvius in the past 10 ka has produced the Plinian eruptions known as Pomici di Mercato [8.8 ka; Aulinas et al. 2008], Pomici di Avellino [3.95 ka; Passariello et al. 2009, 2020; Sulpizio et al., 2010; Sevink et al., 2011] and Pomici di Pompei [79 AD, Sigurdsson et al., 1985]; Campi Flegrei have generated the Pomici Principali [12 ka, Di Vito et al., 1999; Smith et al., 2009] and Agnano-Monte Spina eruptions [4.55 ka; de Vita et al., 1999; Smith et al., 2011].

Comparative archaeological and volcanological studies conducted in Campania show that the effects of the Vesuvius and Campi Flegrei eruptions have strongly influenced the growth and decline of many human settlements over the millennia. The long history of volcanoes impacting human occupation is recorded in detail in the stratigraphy in areas both close to the volcanoes and farther away, in the Apennines, up to several tens of kilometres east and north of the eruption vents [Talamo, 1999; Marzocchella, 2000; Albore Livadie et al., 2005, 2019; Talamo and Ruggini, 2005; Di Vito et al., 2009, 2019; Laforgia et al., 2009]. In fact, paleosols separating the different tephra deposits, and in some cases the tephra itself, contain traces of human presence. Volcanic eruptions and associated phenomena have often caused interruptions in the occupation of these areas, but they have also contributed to the exceptional fertility of the soils, which allowed intense agricultural activity. Moreover, the accumulation of significant quantities of loose ash deposits on the slopes of the hills surrounding the Plain has resulted in repeated lahar generation and flooding episodes, causing the development of marshlands and the build-up of thick detrital 


\section{Human communities and eruptions in Campania}

layers [Di Vito et al, 1998; 2013; 2019; Zanchetta et al., 2004a, b; Sulpizio et al., 2006]. After large magnitude eruptions, like the Bronze Age Pomici di Avellino Plinian event, the reoccupation of previously densely inhabited areas did not occur until a few centuries later, presumably impeded by the general geomorphological instability of zones that were strongly affected by the deposition and remobilization of the eruption products [Di Vito et al., 2019].

During the periods of quiescence between the various eruptions, generally longer than a human lifespan, ancient people have found it advantageous to establish settlements in this area, not only because of the highly fertile soil and favourable climatic conditions, but also due to its geographical location, which favoured trade with neighbouring territories [Di Vito et al., 2019 and references therein].

Archaeological and volcanological studies have revealed that the eruptions of Neapolitan volcanoes have conditioned human activity since prehistoric times. The occurrence of high intensity explosive eruptions, interspersed with long periods of quiescence, has characterized the last $10 \mathrm{ka}$ of activity of these volcanoes.

In this paper we present the results of geological-archaeological studies, carried out in advance of investigations and excavations for the construction of the Rome-Naples and the new Naples-Bari railway lines, which made it possible a detailed reconstruction of human presence in the central part of the Campania Plain up to the coastal strip, between the late Neolithic and the late Bronze Age. The exceptional value of the present study is due to the continuity of observations over a distance of about $30 \mathrm{~km}$, in different sectors of the Plain and in variable palaeogeographic and palaeoenvironmental conditions and in an area which recorded the occurrence of numerous explosive eruptions from both Campi Flegrei and Vesuvius.

\section{The area studied}

The geological-archaeological investigations were conducted in the central Campania Plain, located between the Cancello hills to the north, the Campi Flegrei to the SW, and Somma-Vesuvius to the SSE. The investigations preceded work for the construction of new railway lines (Figure 1). The area is almost flat, with slight variations in altitude. In addition, it is crossed by the River Clanis, largely coinciding with the course of the Regi Lagni channels, built by the Bourbons in XVI-XVII century (Figure 1).

The new Rome-Naples railway line proceeds from the NW to the $\mathrm{S}$, crossing the territory of Gricignano, and enters the municipality of Caivano near the industrial area, following the direction of the Regi Lagni up to the boundary with Afragola. From Afragola the railway deviates southwest towards Naples, moving away from the River Clanis. The northwestern sector, $7 \mathrm{~km}$ long, is characterized by an elevation between 19 and $23 \mathrm{~m}$ asl. From the site of the present station of Afragola, the railway line starts in the direction of Bari, crossing toward $\mathrm{N}$ the Regi Lagni in the territory of Acerra for about $14 \mathrm{~km}$, then touching the Cancello railway junction and continuing straight.

Going south, the two lines cross the Plain at an elevation between $23 \mathrm{~m}$ and $48 \mathrm{~m}$ asl, in correspondence with the highest area, then arriving after about $1 \mathrm{~km}$ at the Sebeto depression, with a reduction in altitude of at least 15 $\mathrm{m}$ (from 35 to $20 \mathrm{~m}$ asl).

\section{Materials and methods}

The examined stratigraphic and chronological interval includes the sequence of pyroclastic deposits and paleosols overlying the tephra of the Pigna St Nicola (Campi Flegrei, 9533-9201 cal BP) [Di Vito et al., 1999; Smith et al., 2009] and/or Pomici di Mercato (Vesuvius, $8890 \pm 90$ cal. BP) [Santacroce et al., 2008] eruptions (Figure 2). The paleosol overlying one or both of these eruptions has been recognized in all the sequences of the Campania Plain and named Paleosol B by Di Vito et al. [1999]. It is a mature, dark brown paleosol formed during a long quiescence of Campi Flegrei and Somma-Vesuvius in a warm and humid climate, with abundant rainfall. It is dated to between the Neolithic and an early phase of the Eneolithic. The overlying sequence includes the deposits of the following eruptions: Agnano 3 (Campi Flegrei, $>4757$ cal BP), Paleoastroni 2 (Campi Flegrei, 4712-4757 cal BP) and AgnanoMonte Spina (Campi Flegrei, 4482-4625 cal BP) [Di Vito et al., 1999; Smith et al., 2009] occurred during the Eneolithic, at least four units of the Astroni volcano sequence, produced in a short time-span (Campi Flegrei, 40984345 cal BP) [Di Vito et al., 1999; Smith et al., 2009] between the Eneolithic and the Early Bronze Age, and finally 


\section{Mauro A. Di Vito et al.}

the Pomici di Avellino (Vesuvius, $3945 \pm 10$ cal BP) [Passariello et al., 2020 and references therein] during a later phase of the Early Bronze Age (BA2). All the tephra were emplaced by pyroclastic fallout, whereas the Pomici di Avellino were emplaced by pyroclastic density currents preceded by pumice fallout. The latter mostly dispersed further east than the study area. The intercalated palaeosurfaces with evidence of anthropic frequentation have been dated using the overlying tephra. Furthermore, their presence, together with the archaeological finds, has been important for inferring the age of sequences related to secondary phenomena like the emplacement of debris flows and alluvial deposits. Thus the definition of isochronous surfaces has been useful for making correlations also in absence of diagnostic archaeological finds (Figure 3).

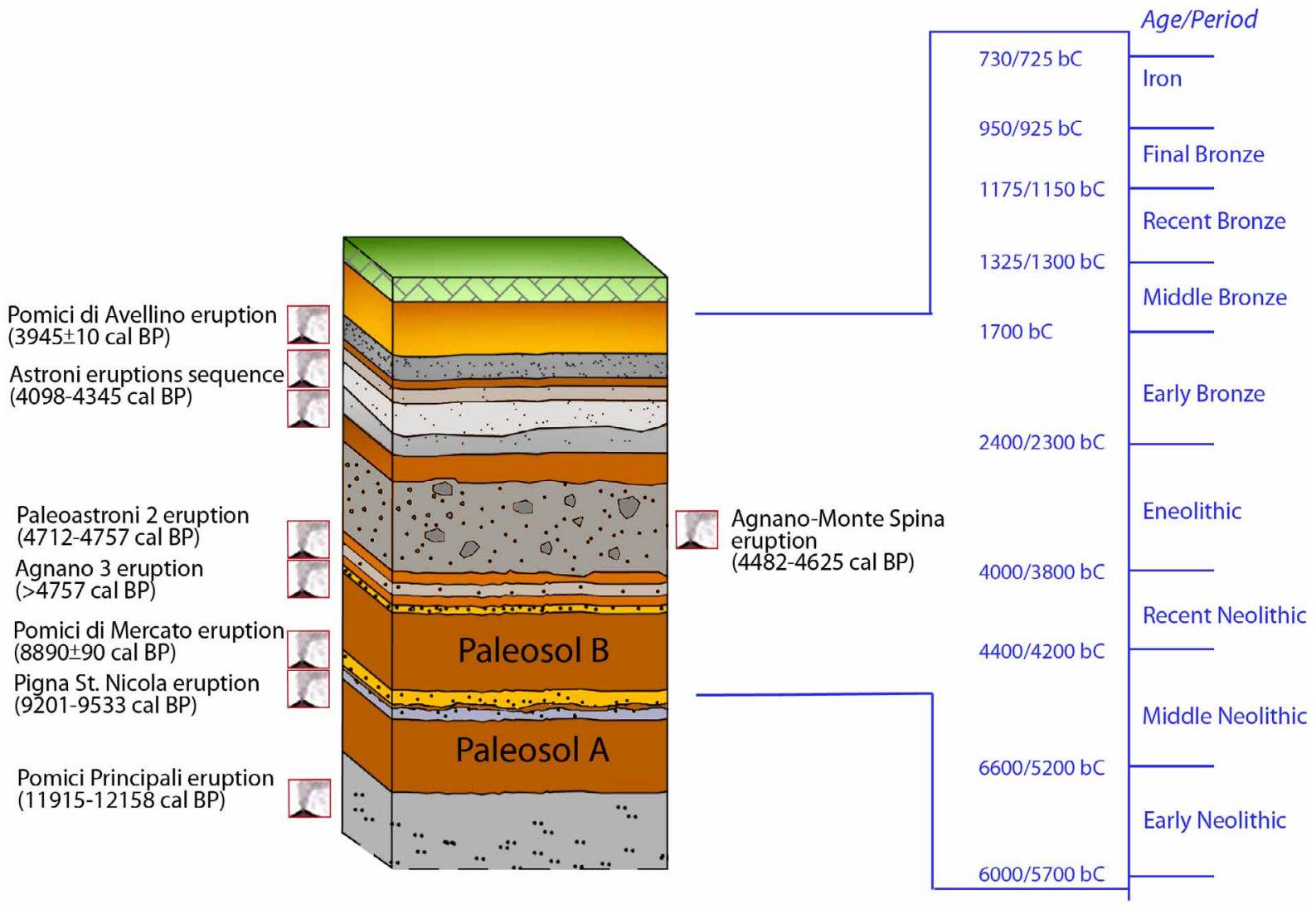

Figure 2. Sequence of pyroclastic deposits of the Campi Flegrei and Somma-Vesuvius eruptions and paleosols (in brown) in the studied area. On the right are the archaeological phases and relative dates (cal BC).

The excavations were studied by a team of archaeologists, volcanologists, palaeomorphologists, micromorphologists, palaeobotanists, physical anthropologists and archaeozoologists. This multidisciplinary approach was deemed necessary given the extraordinary state of preservation of human and animal imprints, structures, traces of agrarian activity and perishable materials such as plants, seeds, leaves and fruits thanks to the eruptive layers. This joint investigation allowed definition on one hand of the characteristics of the volcanic deposits and paleosols, and on the other those of the palaeoenvironment and living areas, and of their possible evolution in relation to natural phenomena and anthropic actions.

During the course of the excavations stratigraphical, sedimentological and lithological data were acquired with the aim to define the emplacement mechanism of the different recognized units and to make correlations among the sequences and paleosurfaces in the studied excavations. This also permitted the attribution of the tephra at the known eruptions cited in the first part of this chapter.

The chronological attribution and the different facies of the investigated contexts was made possible thanks to the analysis of archaeological materials and the comparison with known contexts of central and southern Italy. 


\section{Human communities and eruptions in Campania}

All the geoarchaeological data collected during ten years of excavations, many of them carried out by the authors of this paper, have been revised, contextualized and organised in a GIS database. They provide a detailed picture of human settlements and activities through time with a particular focus both on the period of occurrence of explosive eruptions of both Campi Flegrei and Vesuvius and during their long quiescence.
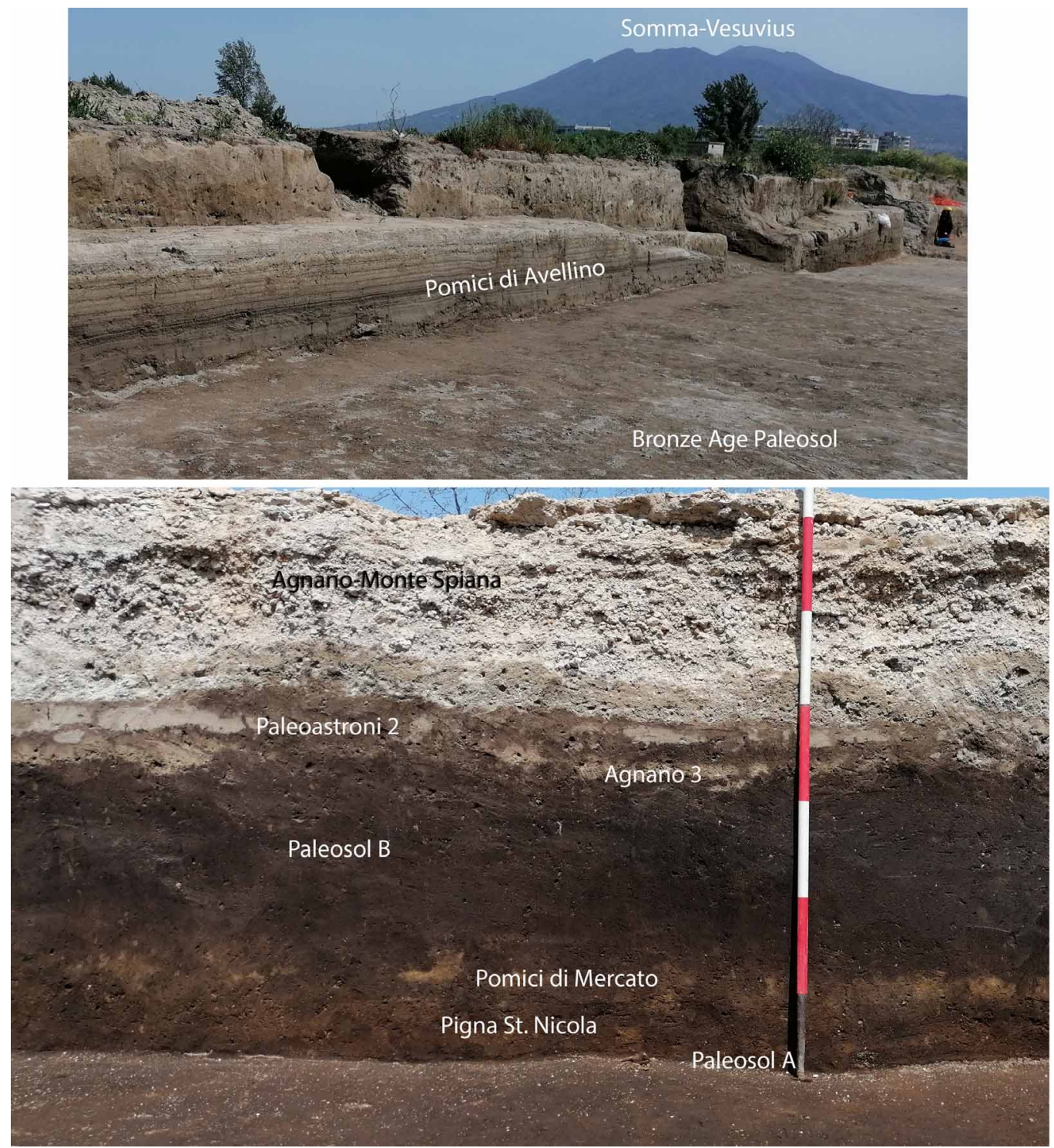

Figure 3. Sequence of pyroclastic deposits and paleosols in excavations in the central part of the studied area (Casalnuovo, Figure 1). The two photos show sections of two limits of excavation. Somma-Vesuvius is in the background.

\section{Results and discussion}

\subsection{The Neolithic period}

The most ancient archaeological horizons, which date to the Late and Final Neolithic (Figure 4), were intercepted within Paleosol B, a mature paleosol formed during a period with a warm and humid climate. In other cases, the archaeological traces are visible directly on top of the Pigna St. Nicola or Pomici di Mercato tephra, as the prolonged exploitation of the soils has often led to the removal of paleosurfaces and higher levels of anthropic use. 


\section{Mauro A. Di Vito et al.}

In the area next to the River Clanis [Nava et al., 2007] there are widespread signs of human activity highlighted by evidence (sporadic hearths, postholes related to fences or light structures, plough furrows) mainly attributable to the agricultural exploitation of the soils and /or in any case to extra-settlement areas, or by the presence in paleosols of pottery finds generally attributable to the Serra d'Alto and Diana archaeological facies.

This evidence is widely present in the southern strip of the Naples-Bari railway route, but has been seen only where deeper excavations have made it possible to investigate the levels concerned. The sector of the Plain that is more elevated and farthest (more than 2-2.5 km) from the hydrographic basins is devoid of traces of frequentation. To the south, the evidence identified along the slope overlooking the Sebeto depression is abundant. There are attestations of the presence of settlement areas, presumably of short duration, which once abandoned were converted to agricultural areas.

These testimonies are connected to those of the Botteghelle site [Giampaola and Stanislao, 2007] and are an indication of the existence of numerous settlements on the most elevated areas immediately close to the Sebeto depression (Figure 4).

\subsection{The Eneolithic period}

Evidence dating to the Early and Middle Eneolithic was detected in the higher portions of Paleosol B and in the paleosols in between the following eruptions of Agnano 3 and Paleoastroni 2 (Figures 3 and 5).

These two eruptions deposited in the area two thin layers of fine ash. Their maximum thickness is decimetric, but they are sometimes affected by erosional processes and agricultural practices (ploughing, hoeing etc.) and these processes have made the layers laterally non-homogeneous and discontinuous. The Paleoastroni 2 ash is stratigraphically higher than Agnano 3 and underlies the Agnano-Monte Spina deposit, from which it is separated by a very thin humified surface (Figure 3).

During these chronological phases the two eruptions seem not to have caused any interruption in the occupation of this area of the Plain. In fact, certain traces of agricultural activities (plough marks, water systems, cultivated soils) are also attested in the area slightly further from the River Clanis, within about $2 \mathrm{~km}$. A similar continuous occupation is reported also in the territory presently occupied by the city of Naples [Giampaola et al., 2018], where excavations have revealed a stratigraphic sequence comparable to that detected in the southern part of the Campania Plain, characterised by overlying ploughed soils alternating with thin eruptive layers from the Agnano 1, 3 and Paleoastroni 2 eruptions [Di Vito et al., 1999].

The continuity of occupation is particularly evident in two settlement areas partially investigated in Caivano and Afragola [Laforgia and Boenzi, 2011], located between 230 and $550 \mathrm{~m}$ from the River Clanis (Figure 6). The earliest phases of occupation were found over Paleosol B, then continuing on top of Agnano 3, and later abandoned after Paleoastroni 2, when the area was used for agricultural activities. The stable occupation of the area is testified also by the Gaudo facies cemetery excavated in the site of Caivano [Laforgia and Boenzi, 2009]. This burial site yielded eight rock-cut tombs with an entrance shaft. Except for tomb 17 which was empty and isolated, the burials seem to have been organised in two different groups.

During a later phase of the Eneolithic period, the area was covered by the pyroclastic fallout deposit of the Agnano-Monte Spina eruption (Figure 3). Despite the accumulation of a thick tephra deposit (several decimetres), its deposition did not cause a long interruption in the occupation of the zone. Above this deposit, the investigated areas did not show the occurrence of deposits connected with significant and prolonged flooding events, as in many other cases in the Plain. This absence can be explained by the high permeability of the Agnano-Monte Spina deposit, composed of coarse pumice lapilli, not favouring stream formation or the occurrence of extensive alluvial phenomena. Furthermore, the deposit is not lithified and poorly cohesive. These features favoured alteration and pedogenetic processes, and the rapid agricultural use of the new surface.

In the southern strip of the Clanis basin, alongside the northern portion of the railway line (Figures 1 and 6), the investigations revealed the presence of roads and a possible ritual pit [Nava et al., 2007; Laforgia and Boenzi, 2011]. Settlements were not detected in this area, but were found further north next to the watercourse in the sites of Carinaro (at Polo Calzaturiero) [Laforgia et al. 2007a, Boenzi, in press] and Gricignano (US Navy area) [Fugazzola Delpino et al., 2003, 2007] located between 2.5 and $3 \mathrm{~km}$ from the river, about $1.5 \mathrm{~km}$ apart.

An intense and dense occupation is attested north of the Regi Lagni in the site of Acerra (about 1.6-2.7 km from 

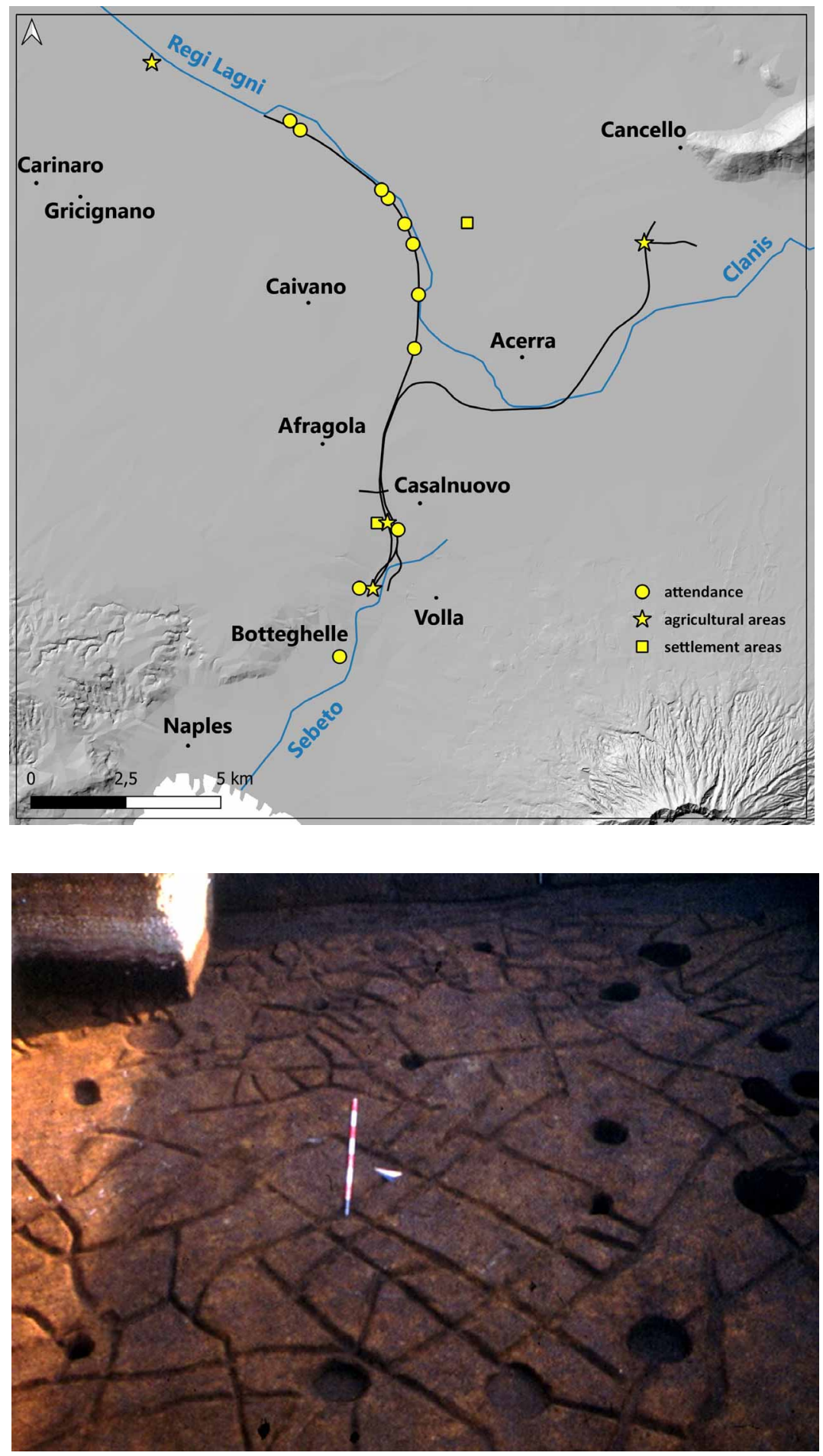

Figure 4. Map of the Recent and Final Neolithic archaeological sites. The black line is the track of the railway. The photo (Volla locality) shows plough marks and postholes on top of the Pomici di Mercato pyroclastic deposit (a thin ash deposit on top of Paleosol A, which is visible in the holes).

the River Clanis) (Figure 6). In Gaudello locality, a large village and adjoining cemetery were discovered in a strategic position at the mouth of the Caudina Valley, which connects the Plain with the Apulia region (Adriatic shore) through the inner Apennines [Aurino and De Falco, in press; Mancusi and Bonifacio, 2020]. These areas, more distant from the Clanis and Sebeto river basins, do not show any traces of farming or settlement activities, but were nevertheless crossed by various overlying roads, in some cases long-lasting ones. 


\section{Mauro A. Di Vito et al.}
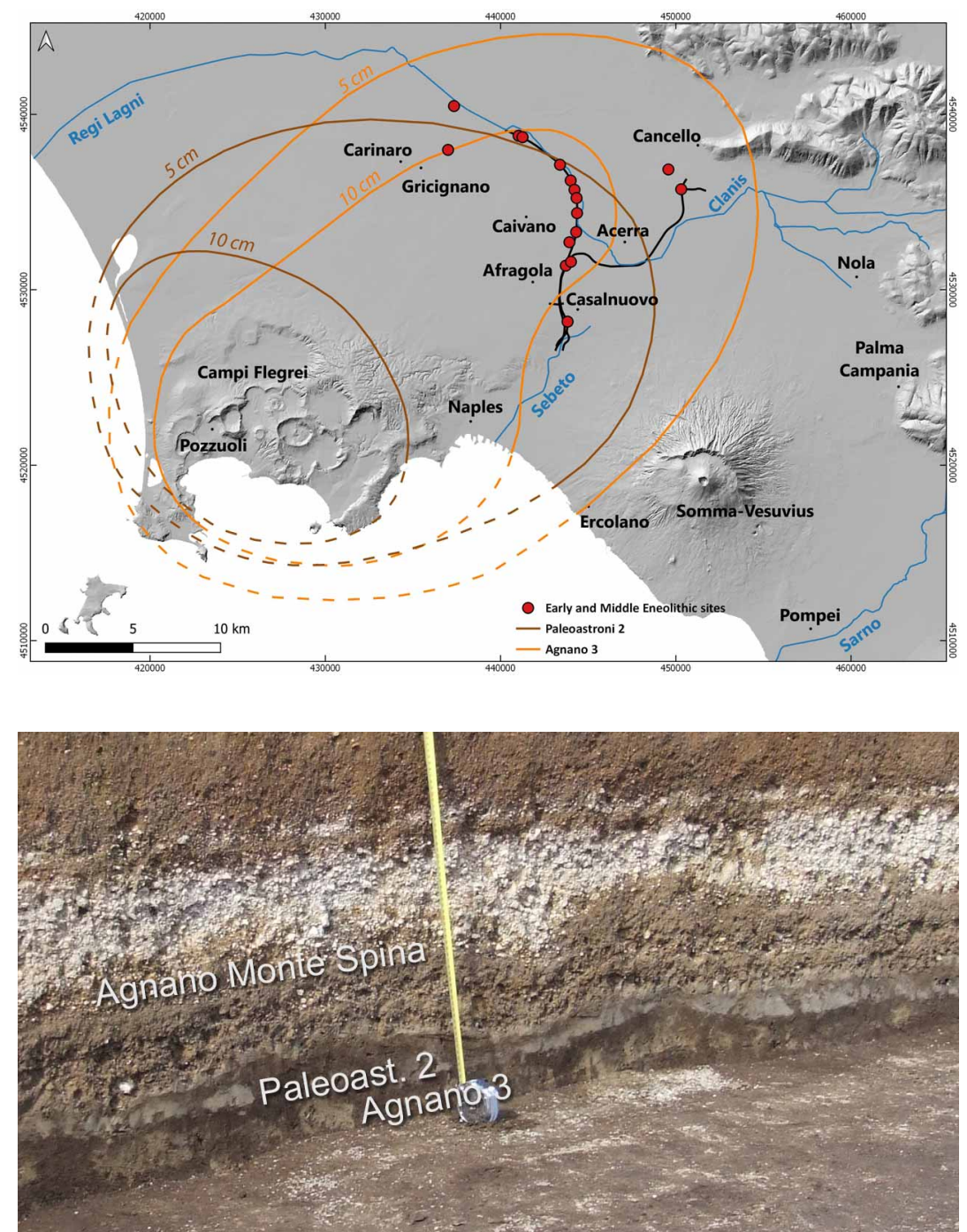

Figure 5. MMap of the distribution (isopachs) of the Agnano 3 (yellow) and Paleostroni 2 (brown) fallout deposits. The red dots indicate sites with Eneolithic evidences. In the photo the sequence of pyroclastic deposits and paleosols is shown. The three pyroclastic units are separated by very thin paleosols.

Nearer to the Sebeto depression, important evidence of living areas was detected. The material culture documented can be dated to a final phase of the Eneolithic period. The pottery repertoire is typical of the late Laterza facies with strong dragged comb/Ortucchio, Bell Beaker or pseudo-Bell Beaker influences [Aurino and De Falco, in press]. This evidence is overlain by thin, fine-ash layers emplaced by the Astroni volcano eruptions, marked by conspicuous traces of agrarian activities indicating a shift in the use of the area (Figure 7). The recent investigations in the eastern part of Naples, at Poggioreale locality, confirmed the dense occupation of the hills overlooking the Sebeto depression [Boenzi and Mancusi, in press]. At present, this is the only trace of an occupation of a site in Naples between the late Eneolithic and the Palma Campania culture of the Early Bronze Age. In this latter period, occupation seems to resume in the coastal area facing the "ancient centre" of the city and in its western portion [Giampaola et al., 2018].

\subsection{The Bronze Age}

The paleosol that developed after deposition of products of the Astroni eruptions, and was overlain by those of the Vesuvian Pomici di Avellino, contains abundant archaeological evidence of the Early Bronze Age (Palma Campania facies). 

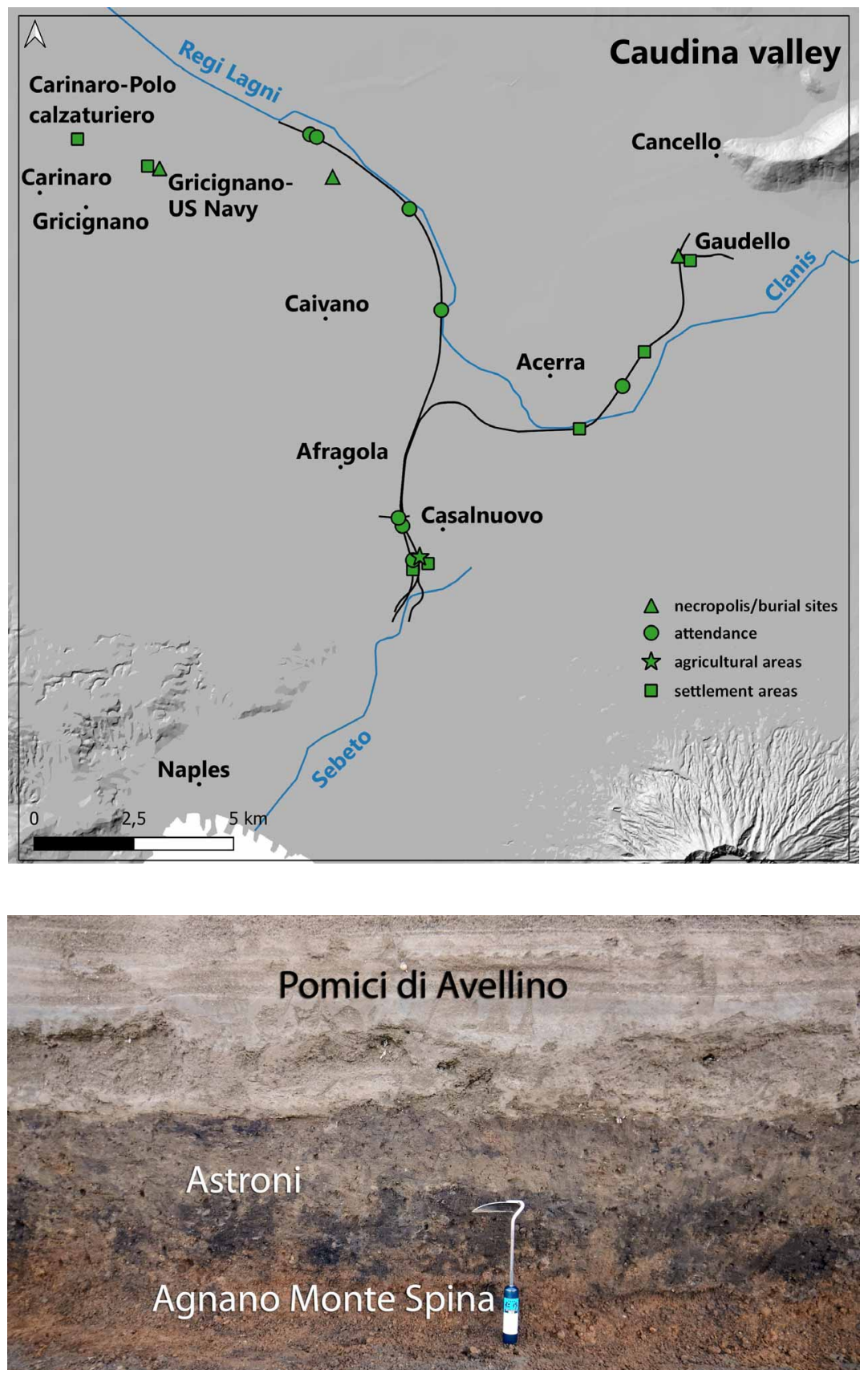

Figure 6. Map of Final Eneolithic archaeological evidence. This was found on top of the Agnano-Monte Spina deposit, where a poorly developed paleosol is present (see section in photo). The black line is the track of the railway.

In this period the area near the River Clanis was once again widely occupied, with evidence attributable to both agricultural exploitation and settlement areas, the latter located in a strip between 200 and $1000 \mathrm{~m}$ from the course of the river (Figure 8). The stratigraphic data clearly indicate that the villages identified, sometimes near one another, were not contemporary, testifying to a considerable mobility of the settlements. Moreover, they were generally all abandoned at the time of the eruption, often for some time. This situation is found both in the south, in the territories of Caivano and Afragola [Nava et al., 2007] and north of the course of the River Clanis. In only one case has a settlement inhabited at the time of the eruption been investigated. It is located in the territory of Afragola, about $1 \mathrm{~km}$ from the course of the River Clanis [Laforgia et al., 2007b, 2009, 2013; Di Vito et al., 2009; Bishop, in preparation]. The investigations made it possible to identify its northern and southern boundaries, while those to the west and east are unknown due to the limits of the excavation. Within the village, buildings with different plans 


\section{Mauro A. Di Vito et al.}

and functions were identified. Ploughed fields appear to have been located near the village, apparently at a distance of no more than $2 \mathrm{~km}$ from the Clanis, while further away than this the only evidence is related to road routes, some of long duration. At this stage, the area near the River Sebeto appears to have been little frequented and characterized by sporadic traces of agricultural work. Just before, during and after the Pomici di Avellino eruption, large areas of the territory were abandoned. The dynamics of escape and migration, but also of temporary return, are evidenced by the traces of human and animal footprints found within and on top of the eruptive deposits and also within the subsequent alluvial layers [Di Vito et al., 2009; Laforgia et al., 2009; Boenzi and Laforgia, in press].

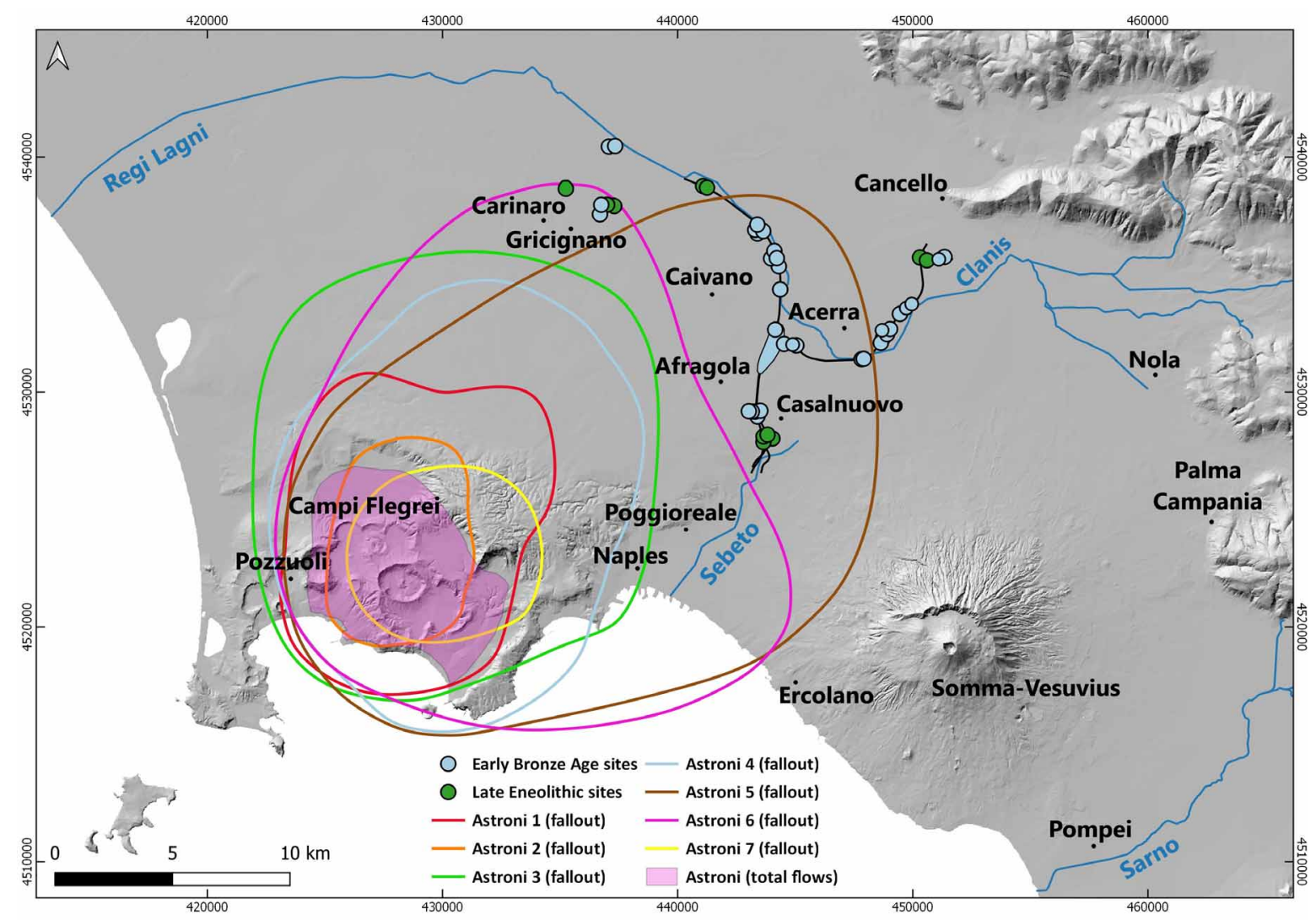

Figure 7. Distribution map of the Astroni pyroclastic units from 1 to 7 ; the lines are the $10 \mathrm{~cm}$ isopachs of the fallout deposits. The late Eneolithic evidence is interbedded with the Astroni sequence, while the Early Bronze Age remains are on the paleosol developed after the Astroni sequence emplacement.

Thick alluvial deposits were generated during a prolonged period of hydrogeological instability in a territory completely modified by the deposition of the eruption products [Di Vito et al., 2019]. The eruption thus seems to have resulted in a significant break in the occupation of the central southern strip of the Campania Plain, demonstrated by the lack of settlements and other activity in a chronological period between the eruption and Middle Bronze Age 3 [Di Vito et al., 2019]. In areas where the effects of the eruption were minor, there were attempts to return and reoccupy the previously inhabited sites [Di Vito et al., 2019], which in the case of Gaudello is evidenced by the installation of new burials in the funerary area [Aurino, in press]. Only in the case of Spiniello, a locality in the territory of Acerra, is there consistent evidence of continuity of occupation between the Early Bronze Age and the Middle Bronze 1-2 and 3, in an area where the effects of the eruption appear particularly limited [Aurino, in press]. This scenario can be applied to all the areas less affected by deposition of the eruption products, such as the Gulf of Naples, the Campi Flegrei, Pompeii and the northern part of the Campania Plain (Capua), where the reoccupation of places is seen in the early Middle Bronze Age, if not at the end of the Early Bronze Age. Along the Naples coast the reoccupation seems to occur in the Middle Bronze 1-2 [Giampaola et al., 2018]. 


\section{Human communities and eruptions in Campania}
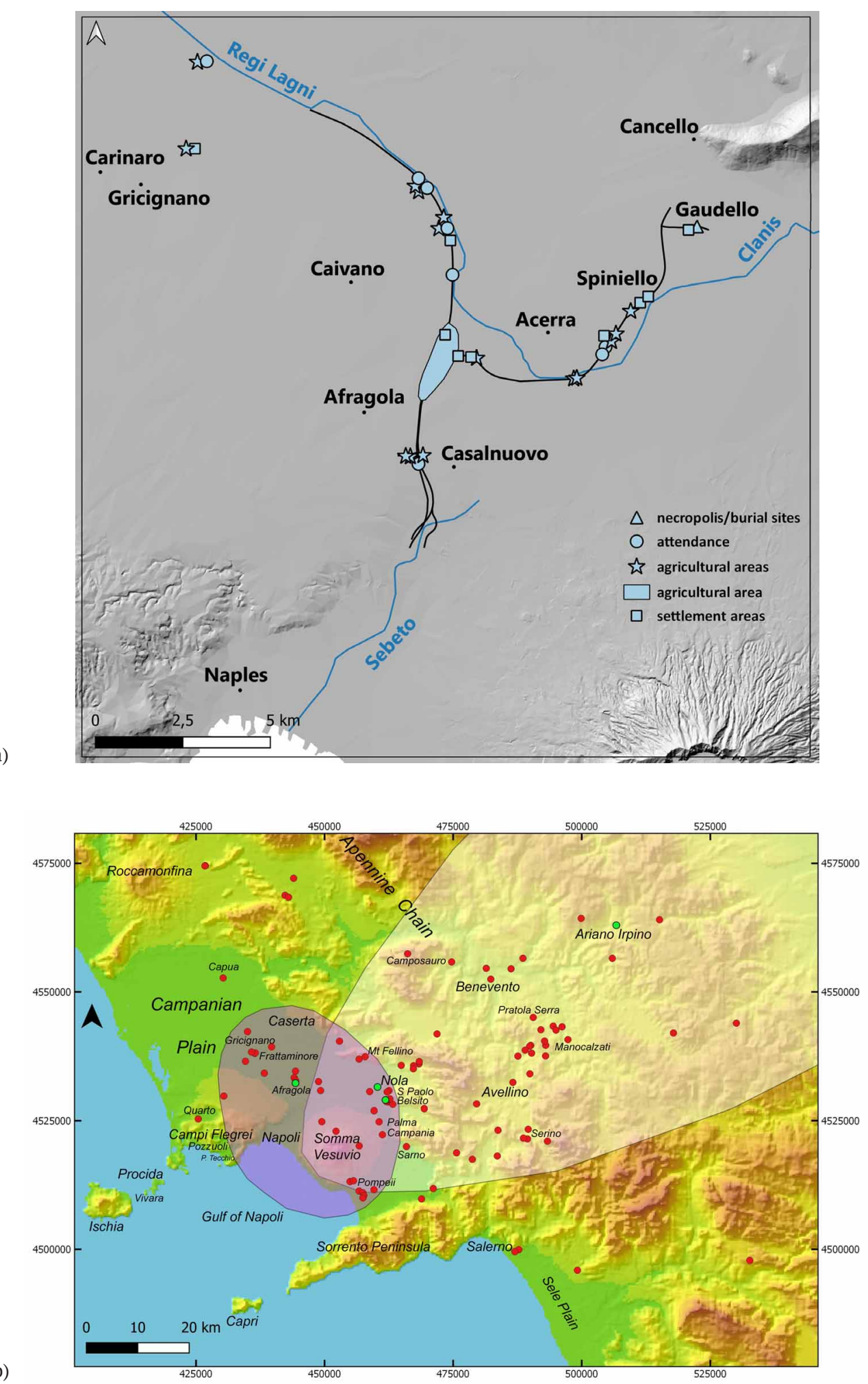

Figure 8. a) Map of the Early Bronze Age archaeological evidence, which was overlain by the Pomici di Avellino deposit. b) Map of the distribution of the Pomici di Avellino deposits (in white the pumice fallout distribution and in pink the PDCs). The red dots indicate Bronze Age sites and green dots resettlement attempts after the eruption (modified after Di Vito et al. [2019]). The black line is the track of the railway. 


\section{Mauro A. Di Vito et al.}

The soil/paleosol formed after the eruption is not particularly well developed. In many cases it has remained in use until today and this prolonged disturbance has led to the removal of evidence relating to its use in the past.

Starting from the Middle Bronze 3 there was widespread reoccupation of the territory characterized by the presence of various substructures (pits, postholes) sometimes attributable to settlement areas. In this period the hydrographic basins of the Clanis (where after the Pomici di Avellino eruption there are consistent traces of sequences of alluvial deposits) and Sebeto rivers also strongly attracted settlement (Figure 9).

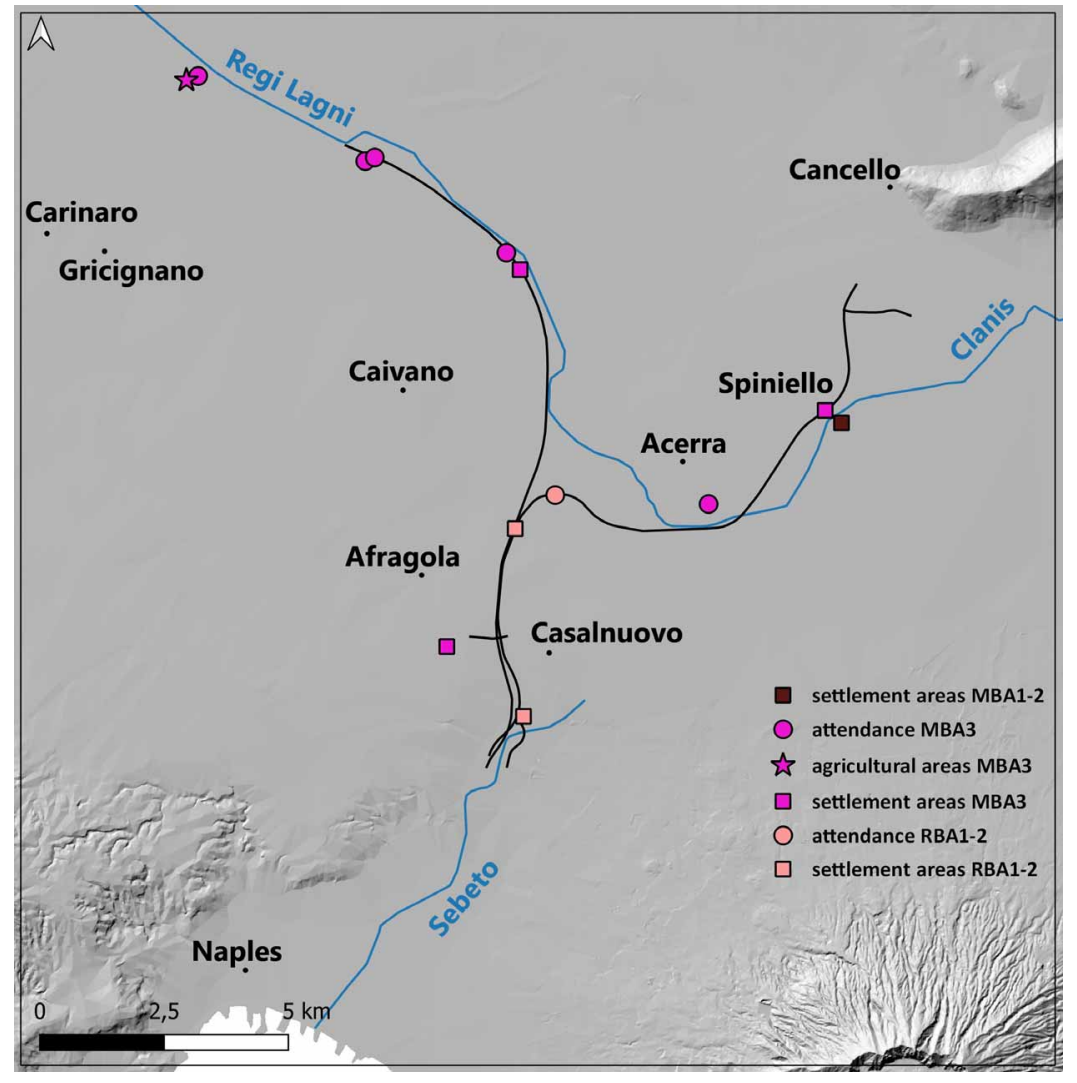

Figure 9. Map of Middle Bronze Age 1-2 and 3 archaeological evidence. The black line is the track of the railway.

Subsequently, in the Recent Bronze Age, it seems that occupation was concentrated in areas that were not settled in the previous phases of the Middle Bronze Age, with important evidence related to two important settlement areas. The first, located about $1.8 \mathrm{~km}$ from the Regi Lagni and about $11 \mathrm{~km}$ from the coast, is apparently characterized by the widespread presence of pits whose fills, in addition to abundant coarse-ware pottery dating to the Recent Bronze 2, have yielded abundant Mycenaean and Italo-Mycenaean material, bronze objects and kiln waste [Laforgia et al., 2007c; Cardarelli, 2009]. The second is located in the territory of Casalnuovo, $3.5 \mathrm{~km}$ southeast of the first and about $7 \mathrm{~km}$ from the sea, where the Plain slopes towards the Sebeto depression. This settlement was surrounded by banks; no imported objects were found there [Nava, 2008; Nava, 2011].

\section{Conclusions}

The data presented and discussed in this paper allow some preliminary conclusions to be drawn.

During the Recent and Final Neolithic sites reached a maximum distance of 2-2.5 km from the course of the River Clanis (now the Regi Lagni) and were located along the slope on the edge of the River Sebeto depression, whereas in the surrounding high areas there is a marked absence of evidence of human presence, as well as in the 


\section{Human communities and eruptions in Campania}

Sebeto morphological depression, characterized by wet-marshy soils both in prehistoric and historical times.

The Agnano 3 and Paleoastroni 2 eruptions deposited only thin ash beds in the Campania Plain which do not seem to have discouraged frequentation of the area, as indicated by the continuity in the use of the land for both settlements and agriculture; a similar continuity is also widely found in the territory of the city of Naples [Giampaola et al., 2018].

The Agnano-Monte Spina eruption resulted in a significant accumulation of pumice and ash layers, but despite their considerable thickness, the eruption does not seem to have led to a prolonged break in the use of the zone. The deposit is very permeable and not very cohesive and this has certainly inhibited large-scale alluvial phenomena and favoured alteration and pedogenesis and resettlement. Once again the settlements seem to have been located close to the river basins, while we do not have significant evidence of agricultural areas. In this phase the settlements appear to have been concentrated near watercourses and wetlands, similarly to the situation documented in the territory presently occupied by the city of Naples, where the areas previously used for widespread cultivation were no longer frequented after the eruption.

The Astroni eruptions, like the other medium-low energy ones already mentioned, do not seem to have determined interruptions in the frequentation of the area. The change in the use of some areas seems rather to have been due to variations in the population structure linked to the mobility of settlements. The latter is evidenced by the presence of very closely spaced settlement nuclei which were evidently not active at the same time.

The Pomici di Avellino eruption main phases greatly affected the entire territory to the northeast of Vesuvius, and only during the final phases (emplacement of PDCs) the territory under examination. This allowed the migration of the populations living in the area (as well attested in the villages of Afragola and Nola, where bronze objects are absent and food and domestic animals also seem to have been largely taken away). These final phases occurred several hours after the beginning of the eruption and the area NW of the volcano was affected by the passage of several PDCs at intervals long enough to allow significant cooling of the ash deposits [Di Vito et al., 2009]. In fact, the first footprints recognized in Afragola are imprinted in the lower ash deposits, still muddy and cool enough. They were probably made by people interested in the recovery of objects from settlements and travelling northwards. After the eruption the area was affected for a long time by the occurrence of intense alluvial phenomena that would certainly have impeded attempts to reoccupy it [Di Vito et al., 2019]. Numerous human and animal footprints found at various stratigraphic heights testify to the passage of organized groups moving away from areas greatly impacted by the eruption and subsequent floods and lahars [Boenzi and Laforgia, in press]. The post-eruption settlements of the Middle Bronze 1-2 developed only in marginal areas not affected by significant phenomena. A substantial reoccupation of the territory did not take place until the Middle Bronze 3, about three centuries after the eruption.

Acknowledgements. A heartfelt thanks goes to the Superintendents who succeeded each other at the helm of the then Soprintendenza Archeologica (S. De Caro, F. Zevi, M.L. Nava, T. Cinquantaquattro) who carried out the complex archaeological protection activity that led to this work as well and to the numerous archaeologists who followed the excavations for the construction of the railway Rome-Naples and Naples-Bari. Two anonymous reviewers are warmly thanked for their contribution to improve the quality of this paper. Sandro de Vita and Jim Bishop are thanked for their fruitful discussions. The presented study has benefited from the financial support of the Presidenza del Consiglio dei Ministri e Dipartimento della Protezione Civile DPC-INGV project, resp. Di Vito M.A., The authors remain responsible for the contents, which therefore do not necessarily reflect the position and official policies of the Department.

\section{References}

Albore Livadie, C., G. Vecchio, E. Castaldo, N. Castaldo, M. Delle Donne, L. Minieri and N. Pizzano (2005). Il villaggio di Nola - Croce di Papa (Napoli) nel quadro della facies culturale di Palma Campania (Bronzo antico), in: XL Riunione Scientifica dell’Istituto Italiano di Preistoria e Protostoria. Lit. Sicignano, Pompei (NA), 54.

Albore Livadie, C., M. Pearce, M. Delle Donne and N. Pizzano (2019). The effects of the Avellino Pumice eruption on the population of the Early Bronze age Campanian plain (Southern Italy), Quatern. Int., 499, 205-220.

Aulinas M, L. Civetta, MA. Di Vito, G. Orsi and D. Gimeno (2008). The Plinian Pomici di Mercato eruption of SommaVesuvius: Magma chamber processes and eruption dynamics, Bull Volcanol., 70, 825-840, doi:10.1007/s00445-007-0172-z. 


\section{Mauro A. Di Vito et al.}

Aurino, P. (2021). La Piana Campana tra la fine del Bronzo Antico e il Bronzo medio: cesure, ritorni e sopravvivenze dalle recenti campagne di scavo ad Acerra (NA), in M. Pacciarelli (ed) Siti chiave tra antico e inizi medio Bronzo nel Lazio e in Campania. Nuovi date e nuove date. Incontro di studio 28 giugno 2018, Università degli Studi di Napoli "Federico II", in press.

Aurino, P. and M. De Falco (in press). Mind the Gap: Bell Beaker presence in Copper Age Campania, Southern Italy, in Proceedings of the $22^{\text {nd }}$ International Meeting of "Archéologie et Gobelets" (Geneva 21-22 January 2021). Archaeopress: Oxford.

Aurino, P., G. Boenzi, M. Di Vito and E. Laforgia (in press). Interazione tra attività vulcanica e assetti insediativi nel settore meridionale della Piana Campana a nord e a sud del fiume Clanis, in Archeologia del cambiamento. Modelli, processi, adattamenti nella Preistoria e Protostoria, Atti della LIV Riunione Scientifica dell'Istituto Italiano di Preistoria e Protostoria, Roma 2019.

Bishop, J. (2021). Il villaggio del Bronzo antico di Afragola e i suoi edifici, in preparation

Boenzi, G. (2021). L'insediamento tardo-eneolitico di Carinaro - Polo Calzaturiero. I saggi di scavo nell'area SE, in preparation

Boenzi, G. and E. Laforgia (in press). Afragola: la frequentazione dopo l'eruzione vesuviana delle Pomici di Avellino, in M. Pacciarelli (ed) Siti chiave tra antico e inizi medio Bronzo nel Lazio e in Campania. Nuovi date e nuove date. Incontro di studio 28 giugno 2018, Università degli Studi di Napoli “Federico II”, cds.

Boenzi, G. and V.G. Mancusi (2021). On the edge of the swamp. Absorption and transformation of the Bell-Beaker phenomenon in the later Copper Age settement of Poggioreale (Naples), in Proceedings of the $22^{\text {nd }}$ International Meeting of "Archéologie et Gobelets" (Geneva 21-22 January 2021). Archaeopress: Oxford, in press.

Bonardi, G., B. d'Argenio and V. Perrone (1988). Carta geologica dell'Appennino Meridionale: 74th Congresso della Società Geologica d'Italia, Sorrento, September 13-17 1988, Dipartimento di Scienze della Terra, Naples, Consiglio Nazionale delle Ricerche, Rome, scale 1:250,000, 1 sheet.

Brocchini, D., D. Principe, D. Castradori, M.A. Laurenzi and L. Gorla (2001). Quaternary evolution of the southern sector of the Campanian Plain and early Somma-Vesuvius activity: insights from the Trecase 1 well, Miner. Petrol., 73, 67-91.

Cardarelli, A. (2009). The collapse of Terramare culture and growth of new economic and social systems during the Late Bronze Age in Italy, Sc. Ant., 15, 449-520.

D’Argenio, B., T. Pescatore and P. Scandone (1973). Schema geologico dell'Appennino meridionale (Campania e Lucania), Atti del Conv. Moderne vedute sulla geologia dell'Appennino, Acc. Nazion. Lincei, 182, 49-72.

de Vita, S., G. Orsi, L. Civetta, A. Carandente, M. D’Antonio, T. Di Cesare, M.A. Di Vito, R.V. Fisher, R. Isaia, E. Marotta, M. Ort, L. Pappalardo, M. Piochi and J. Southon (1999). The Agnano-Monte Spina eruption (4,100 years BP) in the restless Campi Flegrei caldera (Italy), J. Volcanol. Geotherm. Res., 91, 269-301.

de Vita, S., F. Sansivero, G. Orsi, E. Marotta and M. Piochi (2010). Volcanological and structural evolution of the Ischia resurgent caldera (Italy) over the past $10 \mathrm{ka}$, in: Groppelli, G., Viereck, L. (Eds.), Stratigraphy and Geology in Volcanic Areas, 193-239. Geological Society of America Book Series, Special Paper 464.

Di Vito, M.A., R. Sulpizio and G. Zanchetta (1998). I depositi ghiaiosi della valle dei torrenti Clanio e Acqualonga (Campania centro-orientale): significato stratigrafico e ricostruzione paleoambientale, Il Quat., 11, 273-286.

Di Vito, M.A., R. Isaia, G. Orsi, J. Southon, S. de Vita, M. D’Antonio, L. Pappalardo and M. Piochi (1999). Volcanism and deformation since 12,000 years at the Campi Flegrei caldera (Italy), J. Volcanol. Geotherm. Res., 91, 221246.

Di Vito, M.A., E. Zanella, L. Gurioli, R. Lanza, R. Sulpizio, J. Bishop, E. Tema, G. Boenzi and E. Laforgia (2009). The Afragola settlement near Vesuvius, Italy: The destruction and abandonment of a Bronze Age village revealed by archaeology, volcanology and rock-magnetism, Earth Planet. Sci. Lett., 277, 408-442.

Di Vito, M.A., N. Castaldo, S. de Vita, J. Bishop and G. Vecchio (2013). Human colonization and volcanic activity in the eastern Campania Plain (Italy) between the Eneolithic and Late Roman periods. Quatern. Int., 303, 132141.

Di Vito, M.A., P. Talamo, S. de Vita, I. Rucco, G. Zanchetta and M. Cesarano (2019). Dynamics and effects of the Vesuvius Pomici di Avellino Plinian eruption and related phenomena on the Bronze Age landscape of Campania region (Southern Italy), Quatern. Int., 499, 231-244.

Doglioni, C. (1991). A proposal for the kinematic modelling of W-dipping subductions - possible applications to the 


\section{Human communities and eruptions in Campania}

Tyrrhenian-Apennines system, Terra Nova, 3, 4, 423-434.

Fugazzola Delpino, M.A., A. Salerno, A. Tagliacozzo and V. Tinè (2003). Una comunità della facies di Laterza nella pianura campana: l’area “Forum” di Gricignano-US Navy (CE), Atti IIPP XXXV, 199-214.

Fugazzola Delpino, M.A., A. Salerno and V. Tinè (2007). Villaggi e necropoli nell'area del “Centro Commerciale” di Gricignano di Aversa - US Navy, in Strategie di insediamento fra Lazio e Campania in eta preistorica e protostorica, Atti della XL Riunione Scientifica, (Roma, Napoli, Pompei, 2005), Firenze 2007, vol., II, 521-537.

Giampaola, D. and I. Stanislao (2007). Loc. Botteghelle, Un insediamento del Neolitico avanzato, in Strategie di insediamento fra Lazio e Campania in età preistorica e protostorica, Atti della XL, Riunione Scientifica dell'IIPP, (Roma, Napoli, Pompei, 2005), 606-610.

Giampaola, D., G. Boenzi and C. Bartoli (2018). Napoli: territorio e occupazione in età pre e protostorica, Annali di Archeologia e Storia Antica, 25, 207-245.

Ippolito, F., F. Ortolani and M. Russo (1973). Struttura marginale tirrenica dell'Appennino Campano: reinterpretazione di dati di antiche ricerche di idrocarburi, Mem. Soc. Geol. Ital., 12, 227-250.

Laforgia, E., G. Boenzi and M. Viscione (2007a). Un insediamento dell'Eneolitico finale a Carinaro: dati preliminari dagli scavi condotti all'interno del Polo Calzaturiero, in Strategie di insediamento fra Lazio e Campania in età preistorica e protostorica, Atti XL Riunione Scientifica dell'Istituto Italiano di Preistoria e Protostoria (Roma Napoli, Pompei 2005), II, 623-626.

Laforgia, E., J. Bishop, G. Boenzi, A. de Filippis, F. Moscato, A. Mazzocchi, M.A. Di Vito and R. Isaia (2007b). Afragola (NA), Un insediamento del Bronzo Antico distrutto dall'eruzione delle Pomici di Avellino, in Strategie di insediamento fra Lazio e Campania in età preistorica e protostorica, Atti XL Riunione Scientifica dell'Istituto Italiano di Preistoria e Protostoria (Roma Napoli, Pompei 2005), 932-934.

Laforgia, E., G. Boenzi, M. Bettelli, L. Vagnetti and F. Lo Schiavo (2007c). Recenti rinvenimenti dell'età del bronzo ad Afragola (NA), in Strategie di insediamento fra Lazio e Campania in età preistorica e protostorica, Atti della XL Riunione Scientifica dell’IIPP, (Roma, Napoli, Pompei 2005), 935-939.

Laforgia, E. and G. Boenzi (2009). La necropoli eneolitica di Caivano (Napoli), Rivista di Scienze Preistoriche, LIX, 181-218.

Laforgia, E., G. Boenzi, L. Amato, J. Bishop, M.A. Di Vito, L. Fattore, M. Stanzione and F. Viglio (2009). The Vesuvian "Pomici di Avellino“ eruption and Early Bronze Age settlement the middle Clanis Valley, Méditerranèé, 112, 101-107.

Laforgia, E. and G. Boenzi (2011). Nuovi dati sull'occupazione della piana campana a sud del Clanis nel corso dell'eneolitico: le indagini lungo la linea A.V. nei comuni di Caivano e Afragola, in L'età del Rame in Italia, Atti XLIII Riunione Scientifica dell'Istituto Italiano di preistoria e Protostoria, Bologna 26-29 novembre 2008, 249-256.

Laforgia, E., G. Boenzi, L. Amato, J. Bishop, L. Fattore, M. Stanzione and M.A. Di Vito (2013). L'impatto delle eruzioni vulcaniche nelle aree a nord di Napoli: casi da scavi recenti, AIQUA 2013

Mancusi, V.G. and G. Bonifacio (2020). Tra facies e culture: il caso della necropoli del Bronzo Antico in località Gaudello ad Acerra (NA), in IpoTesi di Preistoria, Rivista di contributi e studi di Preistoria e Protostoria, 13, 37-52.

Marzocchella, A. (2000). Storie di contadini alle falde del Vesuvio, Archeo, 182, 36-45.

Nava, M.L., D. Giampaola, E. Laforgia and G. Boenzi (2007). Fra il Clanis e il Sebeto: nuovi dati sull'occupazione della piana campana tra il neolitico e l'età del bronzo, in Strategie di insediamento fra Lazio e Campania in età preistorica e protostorica, Atti della XL Riunione Scientifica, (Roma, Napoli, Pompei, 2005), I, 101-126.

Nava, M.L. (2008). Le attività della Soprintendenza per i beni archeologici delle province di Napoli e Caserta nel 2007, in Atti Taranto, XLVII, (Taranto 2007), 787-891.

Nava M.L. (2011). La Campania settentrionale tra preistoria e protostoria: la situazione attuale, in Gli Etruschi e la Campania settentrionale, Atti del XXVI Convegno di Studi Etruschi e Italici (Capua-Teano 2007), 39-51.

Orsi, G., S. de Vita, M.A. Di Vito, R. Isaia, R. Nave and G. Heiken (2003). Facing Volcanic and Related Hazards in the Neapolitan Area, Earth Science in the City: A Reader, 121-170.

Passariello, I., C. Albore Livadie, P. Talamo, C. Lubritto, A. D’Onofrio and F. Terrasi (2009). ${ }^{14}$ C Chronology of Avellino Pumices eruption and timing of human reoccupation of the devastated region, Radiocarbon, 51, 2, 803-816.

Passariello, I., F. Marzioli, M. Capano, A. D’Onofrio and F. Terrasi (2020). Le datazioni assolute dell'eruzione, in C. Albore Livadie, G. Vecchio (a cura di), Nola Croce del Papa. Un villaggio sepolto dall'eruzione vesuviana delle 


\section{Mauro A. Di Vito et al.}

Pomici di Avellino, 63-69.

Poli, S., S. Chiesa, P.-Y. Gillot, A. Gregnanin and F. Guichard (1987). Chemistry versus time in the volcanic complex of Ischia (Gulf of Naples, Italy): evidence of successive magmatic cycles, Contrib. Mineral. Petrol., 95, 322-335.

Principe, C., M. Rosi, R. Santacroce and A. Sbrana (1987). Explanatory notes to the geological map, in SommaVesuvius, ed. R. Santacroce, CNR Quad. Ric. Sci., 114, 11-52.

Rosi, M., A. Sbrana and L. Vezzoli (1988). Correlazioni tefrostratigrafiche di alcuni livelli di Ischia, Procida e Campi Flegrei, Mem. Soc. Geol. Ital., 41, 1015-1027.

Santacroce, R., R. Cristofolini, L. La Volpe, G. Orsi, G. and M. Rosi (2003). Italian active volcanoes. Episodes, 26, 3, 227-234.

Santacroce, R., R. Cioni, P. Marianelli, A. Sbrana, R. Sulpizio, G. Zanchetta, D.J. Donahue and J.L. Joron, (2008). Age and whole rock-glass compositions of proximal pyroclastics from the major explosive eruptions of SommaVesuvius: a review as a tool for distal tephrostratigraphy, J. Volcanol. Geotherm. Res., 177, 1-18.

Scarpati, C., Perrotta, A., Lepore S., Calvert, A. (2013) Eruptive history of Neapolitan volcanoes: constraints from 40Ar-39Ar dating, Geol. Mag. 150, 3, 2013, 412-425. c_ Cambridge University Press 2012412 doi:10.1017/S0016756812000854

Sevink, J., M.J. van Bergen, J. van der Plicht, H. Feiken, C. Anastasia and A. Huizinga (2011). Robust date for the Bronze

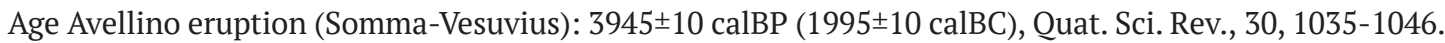

Sigurdsson, H., S. Carey, W. Cornell and T. Pescatore (1985). The eruption of Vesuvius in A.D. 79, Nat. Geogr. Res., 1, 332-387.

Smith, V.C., R. Isaia and N.J.G. Pearce, (2011). Tephrostratigraphy and glass compositions of post- 15 ka Campi Flegrei eruptions: implications for eruption history and chronostratigraphic markers, Quat. Sci. Rev., 30, 3638-3660.

Sulpizio, R., G, Zanchetta, F. Demi, M.A. Di Vito, M.T. Pareschi and R. Santacroce (2006). The Holocene syneruptive volcaniclastic debris flows in the Vesuvian area: geological data as a guide for hazard assessment, in: Siebe, C., Macias, J.L., Aguirre-Diaz, G.J. (Eds.), Neogene-Quaternary Continental Margin Volcanism: a Perspective from Mexico, GSA Special Paper, 402, 203-221.

Sulpizio, R., R. Cioni, M.A. Di Vito, D. Mele, R. Bonasia and P. Dellino (2010). The Pomici di Avellino eruption of Somma-Vesuvius (3.9 ka BP). Part I: stratigraphy, compositional variability and eruptive dynamics, Bull. Volcanol., 72, 539-558.

Talamo, P. (1999). La ricerca a Pratola Serra e nella Valle del Sabato, in: Livadie, C. Albore (Ed.), L'eruzione vesuviana delle "Pomici di Avellino" e la facies di Palma Campania (Bronzo Antico), Atti del Seminario Internazionale di Ravello, 15-17 luglio 1994, 273-284.

Talamo, P. and C. Ruggini (2005). Il territorio campano al confine con la Puglia nell'età del Bronzo, in: Gravina, A. (Ed.), Atti $25^{\circ}$ Convegno sulla Preistoria-Protostoria della Daunia (San Severo 2005), 171-188.

Zanchetta, G., R. Sulpizio and M.A. Di Vito (2004b). The role of volcanic activity and climate in alluvial fan growth at volcanic areas: an example from southern Campania (Italy), Sediment. Geol., 168, 249-280.

Zanchetta, G., R. Sulpizio, M.T. Pareschi, F.M. Leoni and R. Santacroce (2004a). Characteristics of May 5-6, 1998 volcaniclastic debris flows in the Sarno areas (Campania, southern Italy): relationships to structural damage and hazard zonation, J. Volcanol. Geotherm. Res., 133, 377-393.

*CORRESPONDING AUTHOR: Mauro A. DI VITO,

Istituto Nazionale di Geofisica e Vulcanologia, Sezione di Napoli - Osservatorio Vesuviano, e-mail: mauro.divito@ingv.it

(c) 2021 the Author(s). All rights reserved. 